\title{
Ensuring good nutritional status in patients with Parkinson's disease: challenges and solutions
}

This article was published in the following Dove Press journal:

Journal of Parkinsonism and Restless Legs Syndrome

12 December 2014

Number of times this article has been viewed

\author{
Luciana Baroni' \\ Cristina Zuliani \\ 'Primary Care Unit, Northern \\ District, Azienda ULSS 9 Treviso, Italy; \\ ${ }^{2}$ Department of Neurology, General \\ Hospital, Mirano, Venice, Italy
}

\begin{abstract}
Nutrition is becoming an important tool in the management of the main chronic diseases, including Parkinson's disease (PD). Nutritional status has been shown to deteriorate with the progression of $\mathrm{PD}$, due to motor and nonmotor complications. Dietary protein can reduce the effectiveness of levodopa treatment in $\mathrm{PD}$ patients, since the large neutral amino acids and levodopa share the same saturated carrier system, while fiber can improve the drug bioavailability. Moreover, nutrition seems to be directly involved in PD risk: high dietary intakes of animal fat, iron, mercury, and dairy, as well as western dietary patterns can increase it, while intake of some antioxidant compounds and plant-based dietary patterns can be protective. The means of ensuring good nutritional status in PD range from providing adequate energy and nutrients for the body, to considering in a broader perspective, the management of motor and nonmotor symptoms and chronic levodopa treatment complications, as well as pursuing potential neuroprotection. This review summarizes the most relevant results in the literature, and discusses the contribution of diet in the management of PD.
\end{abstract}

Keywords: levodopa, Mediterranean diet, plant-based diet, protein-redistribution diet, vegetarian diet

\section{Introduction}

Nutrition is becoming an important tool in the management of some of the main chronic diseases, not only from the point of view of bodily nutritional requirements. Food can provide protective as well as harmful factors, which can act over time with cumulative, synergic, or antagonistic effects, influencing not only the onset of a disease, but the rate of progression as well. The role of food, namely dietary protein, in levodopa-treated Parkinson's disease (PD) patients was first described as far back as $1975,{ }^{1}$ but even if many authors feel that nutrition should become a part of the therapeutic strategy in PD management, this issue is still poorly addressed by current research. To date, few intervention studies have been performed, while information on hazardous and protective dietary factors comes mainly from nutritional epidemiology. Although single and multiple genetic factors are involved in PD pathogenesis, ${ }^{2-5}$ research suggests that the disease can represent the final pathway of a combination of genetic and environmental factors. ${ }^{6-8}$ Dietary factors can alter the oxidative balance in the brain, and provide both environmental neurotoxins and neuroprotection. Although PD occurs worldwide, its prevalence is two- to five-times higher in industrialized countries than in developing countries, ${ }^{9}$ and is higher in US migrant groups than in subjects of the same ethnicities living in their country of origin. ${ }^{10}$ The lowest prevalence ratios have been reported in People's Republic of China, Japan, and Africa, ${ }^{11}$ countries where plant foods are 
staples in the diet, suggesting that they may contain protective compounds. ${ }^{12}$ In PD, body weight gain and loss can also occur, and both changes in energy expenditure and food intake may contribute. Moreover, food is involved in the pharmacokinetics of the gold standard of treatment: levodopa.

Thus, ensuring a good nutritional status in PD ranges from providing adequate energy and nutrients for the body, to considering, in a broader perspective, the management of motor and nonmotor symptoms and chronic levodopa treatment complications, as well as pursuing potential neuroprotection.

\section{Nutritional status in PD}

PD patients have been found to be at risk for weight changes and malnutrition. Inadequate intake of energy and nutrients cause weight loss and malnutrition, which in turn may worsen the neurological status, and is associated with many adverse outcomes related to health and quality of life. ${ }^{13-15}$ Most studies on PD patients reported weight loss, which correlated with disease progression and motor disabilities, but also with the age at diagnosis and the presence of psychiatric symptoms. ${ }^{16}$ One meta-analysis concluded that PD patients had a significantly lower body mass index (BMI) than controls, with the lowest BMIs in the most advanced stages. ${ }^{17}$ A systematic review reported a malnutrition prevalence range of $0 \%-24 \%$, while $3 \%-60 \%$ of PD patients were found to be at risk. ${ }^{18}$ During a 3 -year follow-up period, the percentage of PD patients at risk of malnutrition increased from $22.9 \%$ to $34.3 \% .{ }^{19}$ Loss of appetite, constipation, early satiety, and swallowing problems were the more frequent symptoms influencing food intake; older age at diagnosis, living alone, higher neurologic and depression scores, and higher levodopa-equivalent-daily-dose/body weight $(\mathrm{mg} / \mathrm{kg})$ ratio predicted malnutrition. ${ }^{20,21}$ The lighter PD patients received greater cumulative dosages of levodopa/ $\mathrm{kg}^{22}$ and BMI correlated negatively with the daily levodopa dosage $/ \mathrm{kg}$ and total dopaminergic dosage $/ \mathrm{kg} .{ }^{23}$ Dyskinetic patients, whose body weight decreased during the course of the disease, received higher total levodopa daily dose, and higher levodopa/kg daily dose. Weight loss and levodopa/ $\mathrm{kg}$ daily dose turned out to be the only significant factors for dyskinesia, ${ }^{24}$ suggesting the existence of a downward spiral linking body weight, levodopa dosage, and dyskinesia.

Weight loss and malnutrition seem to be multifactorial events in PD: some of the motor symptoms associated with the disease (ie, involuntary movements like tremors and dyskinesia) can increase energy expenditure, while other disease symptoms and medication side effects can limit food intake. Finally, PD-related psychosocial and cognitive limitations can increase susceptibility to malnutrition.

While levodopa correlates with weight loss, other dopaminergic agents can cause weight gain, ${ }^{25}$ and increase the risk of compulsive behavior, including compulsive eating. ${ }^{26,27}$ Weight gain was also reported in patients that underwent deep brain stimulation: ${ }^{15,28,29}$ it correlated inversely with the preoperative weight; was more pronounced in bilateral than unilateral pallidal or subthalamic nucleus surgery, ${ }^{29}$ and was linked to a significant decrease of resting energy expenditure, lipid oxidation, and protein oxidation. ${ }^{30}$

The increase in body weight is also multifactorial, and results from dysregulation of the energy requirement-input balance. It involves not only changes in energy expenditure due to motor improvement/attenuation of involuntary movements, but also the alteration of hypothalamic regulation, and the influence on eating behavior modulated by dopamine and dopaminergic treatment through a direct dopamine-agonist effect on limbic D3 receptors involved in the control of feeding. ${ }^{25,28,31}$ Weight gain despite unaltered eating may be the consequence of reduced energy expenditure. Disruption of homeostatic control results in increased appetite, and compulsive eating behavior may also occur. Hyperdopaminergic eating behavior is characterized by compulsive and nocturnal eating; conversely, hyperphagia in the hypodopaminergic state is part of the synonymous behavior, accompanied by apathy and characterized by random snacking and emotional eating. ${ }^{32}$

\section{Food and pharmacological treatment}

$\mathrm{PD}$ is related to the reduction of brain dopamine content. The amino acid levodopa is the direct biochemical precursor of dopamine, and it is the powerful pharmacological treatment that restores adequate dopamine activity: ${ }^{33}$ unlike dopamine, levodopa can enter the brain, where it is eventually decarboxylated to dopamine. In the early stages of PD, levodopa is highly effective, but with the progression of the disease its delivery to the brain fluctuates, and conversely affects the neurological status. ${ }^{34} \mathrm{PD}$ advanced stages are complicated by motor fluctuations, the "on-off" phenomenon, alternating "off" periods (motor blocks) with "on" periods of normal movements or dyskinesia. Food affects levodopa effectiveness in many ways. As a consequence of multiple interferences, levodopa intestinal absorption can become erratic and cause instability of its plasma concentration, while dissociation between levodopa plasma concentration and its clinical effect may be caused by dietary protein. Gastric mucosa contains 
the enzyme aromatic amino acid decarboxylase, so the gastric accumulation of levodopa can reduce its bioavailability. Gastric $\mathrm{pH}$ and meal characteristics (high energy content of food and meal size) reduce gastric emptying rate. ${ }^{34} \mathrm{~A}$ diet rich in soluble fiber can slow gastric emptying rate, unlike a diet rich in insoluble fiber, ${ }^{35}$ which can even increase levodopa bioavailability. ${ }^{36}$ Finally, even dietary protein can affect levodopa bioavailability. ${ }^{37,38}$ Proteins are biological molecules formed by chains of smaller units, the amino acids; they represent, together with carbohydrates and lipids, the dietary macronutrients, because they provide energy. Protein functions are moreover not primarily energetic, as they contribute to the structure of the tissues and perform regulatory, catalytic, and transport actions. As levodopa belongs to the class of large neutral amino acids (LNAA), its entry into the bloodstream and through the blood-brain barrier (BBB) depends on the active saturable carrier system: the LNAA transporter. So, at both levels, levodopa competes for the carrier with the other dietary LNAA (tyrosine [the precursor of levodopa], phenylalanine, leucine, isoleucine, valine, tryptophan, and methionine) to cross gut mucosa and the BBB. As the equilibrium constant for LNAA active transport across the BBB is about ten-times less than for other tissues, and approaches the sum of postprandial LNAA concentrations, the critical site of interference for levodopa transport is at the BBB. ${ }^{39}$ In 1975, the beneficial effect in fluctuating PD patients of a low-protein diet (10 g/day) on neurological status, and on total levodopa requirements, was first reported. ${ }^{1}$ Since then, analogous clinical trials confirmed the benefit of dietary protein restriction and the influence of dietary protein on levodopa effectiveness, which correlated with plasma LNAA levels (with variability among studies), ${ }^{40-45}$ but not with blood levodopa levels. ${ }^{43-48}$ Accordingly, in patients with moderate to severe symptoms, some authors described higher protein intakes (1.27 versus $1.07 \mathrm{~g} / \mathrm{kg}$ ), which correlated with higher daily levodopa dosages. ${ }^{49}$ In one study, the administration of a balanced carbohydrate:protein (5:1) mixture was also effective. ${ }^{50}$ To avoid the risk of nutritional deficits, as far back as 1988, the "protein redistribution diet" (PRD) was proposed, in which protein intake, while not restricted, is concentrated in the evening meal, thus limiting protein interference in the daytime. PRD was effective in the long-term, giving significant reduction of diurnal motor fluctuations, ${ }^{51-53}$ although some authors reported that this benefit was limited to postprandial dose failures. ${ }^{54} \mathrm{~A} 48$-month successful follow-up, with $70 \%$ still-compliant patients, was reported, ${ }^{55}$ while other authors had about $40 \%$ noncompliant patients after a 3 -month period. ${ }^{56}$ PRD acceptability seemed to progressively decrease over time.${ }^{57}$ Current PD guidelines recommend protein intake manipulation for levodopa-treated fluctuating patients. ${ }^{58}$ This intervention is effective in patients who had previously benefited from levodopa therapy, and its positive effect can already be seen within a week. ${ }^{59}$ Benefit appears to be higher when the dietary intervention is applied in the early stages of PD. ${ }^{57}$ Timing of levodopa doses in relation to mealtime is also important: the drug should be introduced no less than 30 minutes before meals, in order to reach the small-intestine quickly and unaltered, and to avoid erratic absorption due to the various effects of food. ${ }^{34}$

\section{Neuroprotection in PD}

Growing evidence suggests that environmental and lifestyle habits, including nutrition, can play protective or detrimental roles in PD. Various food components can elicit neuroprotection, or trigger or exacerbate neurodegeneration, possibly also serving as a vehicle for environmental neurotoxins. ${ }^{60-62}$ Therefore, identifying dietary and lifestyle variables associated with PD may offer pathogenetic clues, and therapeutic and prevention opportunities.

Research supports the role of oxidative stress and lipid peroxidation in $\mathrm{PD}$, which can also promote alpha-synuclein aggregation, a well-recognized event in the pathogenesis of the disease. ${ }^{63,64}$ Hence, it can be supposed that antioxidant molecules (ie, vitamins $\mathrm{E}$ and $\mathrm{C}$, carotenoids, and other phytochemicals) can potentially play a protective role by neutralizing free radicals and preventing neuronal injury in the substantia nigra ${ }^{65}$ Among all dietary antioxidants, only vitamin $\mathrm{E}$ consumption has consistently proven to be protective: higher intakes were shown to reduce PD risk in population studies and in one meta-analysis. ${ }^{66-69}$ Only vitamin $E$ intake from food was effective, not intake through supplements. ${ }^{69}$ Vitamin E was also able to suppress signaling events responsible for microglial activation in cell cultures, suggesting further neuroprotective properties in vivo. ${ }^{70}$ Vitamin $\mathrm{C}$ is highly concentrated in the central nervous system (CNS) and is primarily associated with the activity of glutamatergic neurons. ${ }^{71}$ Although it slowed the progression of the disease in association with vitamin $\mathrm{E}$ in a small pilot trial, ${ }^{72}$ research on this nutrient is still giving conflicting results. ${ }^{65-67,69}$ Carotenoids, the plant-form of vitamin A, also provide antioxidant effects; nevertheless, their serum levels and dietary intakes were shown to be unrelated to PD risk, ${ }^{66,67,69,73}$ although a Japanese study showed a protective effect for higher consumption of dietary beta carotene and vitamin E.$^{68}$ Finally, hyperhomocysteinemia, as well as folate deficiency, can increase neuronal vulnerability to oxidative 
attacks, by decreasing glutathione peroxidase activity and reducing tissue stores of antioxidant vitamins. ${ }^{74}$ So, it was suggested that higher dietary intakes of folate, vitamin B12, and vitamin B6 (cofactors in homocysteine metabolism) could reduce PD risk by decreasing plasma homocysteine levels. Nevertheless, no consistent relation was found with B12 and folate intakes: only vitamin B6 intakes were shown to exert protective effects in most studies. ${ }^{75-77}$ It is also worth mentioning that vitamin B6 can boost dopamine synthesis. ${ }^{76}$ An almost doubled prevalence of vitamin D deficiency in PD patients was recently reported, and low plasma levels correlated with more advanced neurological status. ${ }^{78}$ Vitamin D benefit in PD ranges from bone health to neuroprotection; ${ }^{79}$ however, its adequacy is not dependent on diet, but on sunshine exposure and/or supplementation. For this reason, as we'll see later, nutritional recommendations in PD patients are the same as for the general population. Mercury, a heavy metal that can harm basal ganglia, has been recognized as a risk factor for many years now. ${ }^{80}$ Even iron has been directly related to PD risk, ${ }^{81-83}$ through neurotoxicity from various possible mechanisms: intracellular iron concentration, hydroxyl radical production, and mitochondrial damage. ${ }^{84}$

Studies which evaluated macronutrient intakes have produced inconclusive results: some authors reported that high animal fat intakes increased PD risk, ${ }^{81,85,86}$ while others found no correlation. ${ }^{83,87,88}$ Although the potential mechanisms remain speculative, it is assumed that animal fats (mainly saturated) can induce adverse changes in cell membrane lipid composition via oxidative stress. ${ }^{89}$ They can also interfere with the endogenous metabolism of polyunsaturated fatty acids which, like vegetable fats, seem to be protective or neutral with regards to PD, although few studies are found on this subject. ${ }^{81,86,90-92}$

Juglone, contained in walnuts, has been recently shown to protect brain cells in preclinical studies. ${ }^{93}$ Juglone is an inhibitor of the enzyme Pin1, a major peptidyl-prolyl isomerase, which was found to be present in PD Lewy bodies (markers of the disease, consisting of cytoplasmic inclusions containing aggregates of $\alpha$-synuclein) and to promote the formation of $\alpha$-synuclein inclusions in cellular models. ${ }^{94}$ It was also found that its activity is highly upregulated in cell cultures of PD brains, ${ }^{93}$ suggesting a pathophysiological role of this enzyme in the dopaminergic pathway degeneration, and hence suggesting that walnut intakes can be beneficial for neuroprotection, not only as a source of polyunsaturated fatty acids.

Research focusing on single foods or food groups has shown that dairy product consumption, especially milk, can increase PD risk, ${ }^{95-97}$ and can possibly introduce dopaminergic neurotoxins, such as pesticides and polychlorinated biphenyls. ${ }^{61,98}$ Meat consumption has also been linked to increased PD risk. ${ }^{85}$ Meat, particularly red meat, besides the animal fat it contains, is the unique dietary source of heme iron, the bioavailability of which is high and cannot be downregulated. As previously described, iron can cause CNS damage. ${ }^{84}$ Fish consumption can contribute to a high level of the body's mercury burden, thus increasing PD risk. ${ }^{80}$ Although mercury contamination has usually been associated with saltwater fish, research found that even freshwater fish can contain mercury, due to human activities or to natural causes. ${ }^{99-103}$ The United States Environmental Protection Agency published in 2009 the results of a national study on freshwater fish, reporting that $48.8 \%$ of the sampled population of lakes had mercury tissue concentrations that exceeded the $300 \mathrm{ppb}(0.3 \mathrm{ppm})$ human health Screening Values (SV) for mercury. ${ }^{104}$

While research studies on the role of food in PD are lacking, the effect of a nonessential beverage, namely coffee, has been extensively investigated. As its consumption has been related to a lower PD risk, ${ }^{105-109}$ a protective role of caffeine against dopaminergic degeneration has been suggested. This benefit was found to be fairly strong among men and postmenopausal women not receiving hormone therapy. A negative estrogen-caffeine interaction has been hypothesized. ${ }^{105,107,110-112}$ The protective effect of drinking tea on PD risk was also widely explored, and a recent meta-analysis reported a beneficial, apparently, non-dose-dependent, effect. ${ }^{113}$ Other studies suggested that beneficial effects of tea could be due to its content of polyphenolic compounds, ie, theaflavin in black tea and (-)-epigallocatechin-3-gallate in green tea. ${ }^{61,114}$ Polyphenols can be considered as natural antioxidants and anti-inflammatory agents, as they act not only as radical scavengers and metal chelators, but also as modulators of gene expression, intracellular neuronal signaling and metabolism, and mitochondrial function. ${ }^{115,116}$

As we have seen so far, the overall results of studies exploring the effect of single nutrients or foods on PD risk are still conflicting, confirming how difficult it can be to try to identify a single protective compound among the myriad of potentially protective or harmful ones that compose a single food. Similarly, the opposite approach can also be difficult, ie, to isolate "the" active compound/compounds from a protective or hazardous food. Thus, it might be more informative to examine principle dietary patterns. From this research, it is possible to point out that countries with western dietary patterns, characterized by high consumption of animal foods, show a higher PD prevalence in comparison with countries 
following a mainly plant-based diet. ${ }^{11,117}$ Growing evidence indicates that plant-based dietary patterns, like Mediterranean and vegetarian diets, can reduce the risk of Alzheimer's disease ${ }^{118}$ and $\mathrm{PD},{ }^{119-122}$ as well as plasma inflammatory biomarker concentration, ${ }^{123,124}$ thus potentially contributing to neuroprotection. ${ }^{125}$

Although some parts of the puzzle of data we have reviewed thus far are in some respects lacking and largely unsatisfying, we can try to use the available information to propose a strategy of action, making the most of the complex mixture of nutrients present in plant foods.

\section{Ensuring good nutrition}

In the management of PD, a nutritional approach is warranted for many reasons. First, many studies have reported that PD patients experience a change in body weight and nutritional status. Second, nutrition seems to be directly involved in PD risk, which can manifest, after the clinical onset, as an influencing factor on the progression of neurodegeneration or as a neuroprotective effect: some foods or nutrients, mainly in diets with high intakes of animal fat and dairy products, ${ }^{83,85,95,97,98}$ can increase the risk, while plant-based dietary patterns showed a protective effect. ${ }^{120,122}$ Third, it is well established that diet modification can maximize the result of therapy with exogenous dopamine. ${ }^{126}$

Any nutritional intervention consists of: 1) nutritional assessment (patient's nutritional history and anthropometric measures), which should be performed routinely; ${ }^{127}$ 2) evaluation of actual individual nutritional requirements, which may change with PD progression or after surgical intervention; and 3) a sample menu, which should be correctly planned to avoid the risk of nutritional deficiencies ${ }^{128}$ or nonacceptance caused by new dietary habits. ${ }^{56}$ The nutritional characteristics of the main food groups are summarized in Table 1.

Ideally, the challenge of ensuring good nutrition in PD involves: proposing a dietary regimen composed of nutrientdense food that is easy to adhere to at home through the use of commonly available food; being able to protect against nutritional deficiencies or weight modifications; and being effective in improving motor performances and possibly exerting direct or indirect neuroprotective effects. Given the limited evidence, and following the principle of precaution, the latter should include an emphasis on antioxidant phytochemical intakes (natural plant food) and the exclusion, or at least the limitation, of mercury (fish), iron, animal fat (eggs, meat, and fish), and dairy intakes. This gives rise to a diet mainly based on grains, legumes, vegetables, fruits,
Table I Nutritional characteristics of the main food groups

Grains: important sources of many nutrients, including fiber, several $B$ vitamins (including B6 and folate), minerals (magnesium, zinc, and selenium), carbohydrates, and vegetable protein.

Vegetables: most vegetables are naturally low in fat and calories and are important sources of many nutrients, including fiber, folate, vitamin C, carotenoids, minerals (potassium, calcium, and iron), and phytochemicals. Fruits: most fruits are naturally low in fat, sodium, protein, and calories, and are sources of many essential nutrients, including fiber, vitamin C, carotenoids, folate, carbohydrates, minerals (potassium), and phytochemicals.

Nuts and seeds: calorie-dense food, are important sources of omega-3 fatty acids, fiber, vegetable protein, minerals (calcium, magnesium, zinc, and selenium), vitamin $\mathrm{E}$, and phytochemicals; it is important also to choose unsalted nuts and seeds to help reduce sodium intakes. Legumes: source of carbohydrates, vegetable protein, fiber, minerals (calcium, iron, magnesium), vitamins (including B6), polyunsaturated fatty acids, and phytochemicals.

Fish and other water animals: source of protein, vitamins, minerals (iron), omega-3 fatty acids, eicosapentaenoic acid, and docosahexaenoic acid, but also saturated fats and mercury.

Dairy foods: they are the primary source of calcium in western diets, but also a source of saturated fats and animal protein, and can contain toxic compounds; only the vitamin D-fortified products are good sources of this nutrient. If consumed, it is recommended to consume them in their low-fat or fat-free forms, which provide little or no solid fat. Meat, poultry, and eggs: source of animal protein, cholesterol, saturated fats, vitamins, and minerals (iron). A high intake of fats makes it difficult to avoid consuming more calories than are needed.

nuts, and seeds, where dairy products, eggs, fish, and every kind of meat, if present, are in limited amounts. Such a diet is called a plant-based diet: typical plant-based diets are the original Mediterranean diet and vegetarian diets.

The basic application of a balanced Mediterranean-like dietary regimen in PD patients has been already suggested. Further dietary manipulation (protein redistribution and lowprotein regimens) may be considered after the introduction of levodopa therapy. ${ }^{129}$

\section{General recommendations}

General dietary recommendations for PD patients consist of the proposal of a well-balanced plant-based diet: the menu should comply with the Dietary Reference Intakes (DRIs) for energy, macro- and micronutrients, dietary fiber, and fluids. ${ }^{130}$ The intake of fiber, antioxidants (ie, vitamins $\mathrm{C}$ and E, carotenoids, other phytochemicals), and vitamin B6 in high amounts and from natural sources should always be emphasized ${ }^{61}$ as, to date, clinical trials of nutritional supplementation have provided insufficient evidence to support its routine clinical use for PD. ${ }^{127}$ The possible beneficial effect of coffee and tea should also be taken into account in menu planning for PD patients. 
Diet should satisfy energetic requirements, depending on sex, age, muscle mass, and physical activity; in PD patients energetic requirements can be increased, owing to hypertonic muscle activity and involuntary movements, even though some nonmotor symptoms can contribute to reduce effective food and energy intakes. ${ }^{34}$ Although the occurrence of negative energy balance is more frequent, in some circumstances the opposite situation can occur. Periodic anthropomorphic checks, particularly in patients with advanced disease, permit the monitoring of any energy discrepancies.

Vitamin B12, calcium, vitamin D, and omega-3 fatty acids can represent critical dietary nutrients; the possibility of such deficiencies should be taken into account and prevented. Vitamin B12 (plus folate and homocysteine) and 25-OH vitamin D (25-hydroxy-vitamin D) concentrations should be checked since they are not routinely checked by primary care physicians, despite frequent deficiency in elderly people. ${ }^{127}$

\section{Vitamin BI2}

Even though research has failed to show a link between B12 status and $\mathrm{PD},{ }^{75,76}$ the role of this vitamin for CNS function has been extensively described, ${ }^{131-133}$ and its deficiency is common among the elderly. ${ }^{131,134}$ Unfortunately, ensuring B12 food sources in the diet does not guarantee the prevention of its deficiency, as malabsorption is involved in the majority of cases; many factors can compromise its intestinal absorption, from gastric conditions to the use of some common drugs. ${ }^{135,136}$ For this reason, it is recommended that all people over 50 years of age be supplemented. The crystalline supplement is well absorbed, unlike that which is contained in food. ${ }^{130,137}$ The recommended daily allowance (RDA) of vitamin B12 is $2.4 \mu \mathrm{g}$ from multiple daily intakes. ${ }^{130}$ The once-a-day or the once-a-week intakes require higher amounts, ${ }^{138}$ as B12 bioavailability decreases significantly with increasing doses of single assumptions. ${ }^{134}$ Sublingual formulation should be preferred.

\section{Calcium}

Good dietary sources have to be emphasized. Although dietary intakes below recommended levels might have negative health consequences over the long term, ${ }^{139}$ research shows that calcium intakes are not always related to bone health in people following vegetarian diets. ${ }^{140-142}$ Dairy products are the primary source of calcium in western diets, but their consumption has been related to a higher PD risk. ${ }^{95,97,98}$ Hence, it is possible to satisfy calcium requirements without including dairy food; some nuts and seeds (almonds, sesame), green leafy and cruciferous vegetables, not to mention dairy substitutes fortified with calcium, such as cereal and soy "milks", represent good alternative sources. ${ }^{143,144}$ In the case of low calorie requirements, calcium from mineral water may provide highly absorbable calcium. ${ }^{145}$ As the RDA for calcium is up to $1,200 \mathrm{mg},{ }^{130}$ some authors suggest that calcium supplementation may be useful; in most patients $500 \mathrm{mg}$ per day, or in some $1,000 \mathrm{mg}$ per day, is required to achieve a total intake of $1,200 \mathrm{mg} .{ }^{146}$

\section{Vitamin D}

Apart from any possible role in $\mathrm{PD},{ }^{61}$ its deficiency represents a worldwide problem. ${ }^{147}$ Diet can provide about $10 \%$ of the total requirement, as its natural source is endogenous synthesis and activation. Since many factors can affect the latter, the regular use of D3 or D2 supplements is recommended. The RDAs for vitamin $\mathrm{D}$, which assume minimal sunlight exposure, are $600 \mathrm{IU}(15 \mu \mathrm{g})$ for most adults and $800 \mathrm{IU}(20 \mu \mathrm{g})$ for adults over 70 years of age. ${ }^{130,148}$ Some authors recently suggested that daily supplementation with $800 \mathrm{IU}$ vitamin D is a practical and safe strategy which does not need prior determination of plasma levels. ${ }^{146}$

\section{Omega-3 fatty acids}

Omega-3 fatty acids are provided in the form of alphalinolenic acid (ALA) from plant sources (flaxseed, walnuts), and of docosahexaenoic acid (DHA) and eicosapentaenoic acid (EPA) from fish, which, however, can also contain various amounts of mercury. ${ }^{78,149}$ The adequate intake (AI) for ALA is 1.1 and $1.6 \mathrm{~g} / \mathrm{d}$ for women and men, respectively. ${ }^{130}$ Not only was ALA consumption found to be protective in a metanalysis, ${ }^{91}$ it can be endogenously bioconverted to DHA and EPA in higher amounts if the intakes of total fat, saturated fat, and omega- 6 fat are limited. Hence, the use of monounsaturated fats (ie, olive oil) represents a useful alternative to animal fats and to other common vegetable oils. Nevertheless, some experts suggest an AI of $250 \mathrm{mg} / \mathrm{d}$ of preformed EPA plus DHA for adults. ${ }^{150}$ Although in the general population the health benefits from consuming seaand freshwater fish are considered to outweigh the health risk associated with mercury, ${ }^{137}$ we trust that this postulation should not be applied to PD patients, following the principle of precaution, and fish should be limited/avoided. Even if PD represents a situation where the neuroprotective role of DHA remains speculative, ${ }^{61}$ we trust that a DHA algal supplement 
(200-250 mg/d) should be proposed over the consumption of ALA-rich foods. Algae supplements represent, in fact, an alternative and effective source of preformed DHA. ${ }^{151}$ Table 2 lists the amounts of ALA-rich foods providing about $2.5 \mathrm{~g}$ of ALA. ${ }^{152}$

\section{Levodopa-treated patients}

In addition to the above general recommendations, in levodopa-treated PD patients the diet can be further implemented by limiting to the RDA the daily protein intake and, by its redistribution, concentrating protein intake in the evening meal. Preferring plant protein can also improve fiber intake; both interventions can be expected to raise levodopa bioavailability, and to improve neurological status in responder patients. Even if the literature suggests that protein manipulation should be applied to fluctuating PD patients, we trust that if the dietary intervention allows reducing total levodopa intakes, it should be applied also to nonfluctuating patients. So, responder patients are those who can reduce fluctuations and/or reduce levodopa total intakes.

\section{Protein}

Intakes should provide $0.8 \mathrm{~g} / \mathrm{kg},{ }^{130}$ which should be increased to $1 \mathrm{~g} / \mathrm{kg}$ if protein is derived exclusively from plant sources. ${ }^{153}$ In PD patients, as in the general population, average protein intake is higher than actual body requirements. An Italian study reported that PD patients had an average daily protein intake of $50 \%$ higher than the RDA (1.2 versus $0.8 \mathrm{~g} / \mathrm{kg}) .{ }^{49}$ Choosing plant protein supplies adequate amounts of food without the use of expensive special low-protein products. ${ }^{154}$ LNAA are all indispensable amino acids, and their concentration in plant protein is lower than in animal protein. Nevertheless, plant protein can meet protein requirements when a variety of plant foods is consumed and total energy needs are met, ${ }^{143}$ and can easily limit total protein and excessive LNAA intakes.

Total protein can be redistributed to the extent that less than $10 \%$ of the total daily protein consumption occurs

Table 2 ALA-rich foods: amount providing about $2.5 \mathrm{~g}$ of ALA

\begin{tabular}{ll}
\hline Food & Amount \\
\hline Flaxseed oil & $\mathrm{I} \mathrm{Ts}$ \\
Flaxseeds, ground & $3 \mathrm{Ts}$ \\
Walnuts & $30 \mathrm{~g}$ (about 6 nuts) \\
\hline
\end{tabular}

Note: Amounts calculated using the USDA National Nutrient Database for Standard. ${ }^{152}$

Abbreviations: ALA, alpha-linolenic acid; Ts, teaspoon (about $5 \mathrm{~g}$ ) during the daytime and the rest in the evening. ${ }^{155}$ PRD appears to be well tolerated by patients, and can give near-normal daytime motor function in responder subjects. Its nutritional adequacy, if total protein intake is normal, has been confirmed. Only in patients with marginally adequate diets the intakes of various nutrients, including protein, might be compromised, ${ }^{156}$ as commonly happens in normal individuals when energy intakes are low.

\section{Fiber}

Natural plant foods are the sole source of fiber in the diet. In contrast with animal food, protein-rich plant food (namely legumes and nuts) also provide fiber. Fiber is important for proper bowel function, and a plant-based diet helps by reducing constipation and diverticulosis. ${ }^{157,158}$ As previously discussed, insoluble fiber can potentially raise levodopa bioavailability by reducing the phenomenon of constipation. ${ }^{36}$ The AI range for total fiber is $21-38 \mathrm{~g} / \mathrm{d}$ for adults. ${ }^{130}$

Finally, levodopa dosing modification in relation to meals should be considered (consumption at least 30 minutes before mealtime) in order to limit the interference of postprandial gastric emptying. ${ }^{34}$

\section{Management of nonmotor complications}

Nonmotor symptoms play a significant role in nutritional status and in the progression of the disease, and can heavily affect the quality of life of PD patients. Dysphagia, hyposmia, constipation, gastroparesis, gastroesophageal reflux, loss of appetite, and body weight changes are the main complications of the disease. ${ }^{127,129}$ Fiber-containing food provides a feeling of fullness and satiety with fewer calories, thus representing a benefit, counteracting body weight increase. On the contrary, dysphagia, loss of appetite, and body weight loss require the administration of nutrientdense and calorie-dense food. The administration of juices in place of whole fruit and vegetables can help to fulfill the diet nutritional adequacy and provide fluids when dietary intakes are marginal. The regular consumption of nuts and seeds can provide nutrients and energy in small volumes; these foods can be mashed into creams, or ground and scattered into various dishes. Generous amounts of added oil, in the form of olive oil and small amounts of flaxseed oil, can provide concentrated energy as well as important nutrients (ie, vitamin E and omega-3 fats). If semisolid foods are required, the addition of well-cooked grains to the meal, such as millet, quinoa, and amaranth, or mashed tofu and potato, in place of specific thickening products, can increase the nutritional content of the diet without 
significantly increasing the cost. Frequent nutrient-dense snacks, which can interfere less than a standard meal with gastric emptying and levodopa absorption, can be offered to counteract loss of appetite and gastroparesis. ${ }^{34}$ Severe dysphagia may eventually require percutaneous endoscopic gastrostomy tube placement for nutritional support and more reliable PD medication dosing.

Other complications can be derived from, or can be exacerbated by, pharmacological treatment, eg, nausea, loss of appetite, and orthostatic hypotension, ${ }^{159}$ the latter requiring specific nonpharmacological and pharmacological interventions if symptomatic. Moreover, levodopa therapy is responsible for hyperhomocysteinemia, independent of folate or vitamin B12 deficiency. This metabolic alteration results from methylation of levodopa and dopamine by catechol O-methyltransferase. Hyperhomocysteinemia represents a risk factor for vascular disease and, potentially, dementia and depression, and was associated with a $75 \%$ increased risk for coronary artery disease in a group of PD patients. ${ }^{160}$ These findings have implications for the treatment of PD in patients at risk for vascular disease, and potentially for those at risk for dementia and depression. The reduction of levodopa total intakes, as the result of an improvement in its bioavailability, can help to reduce these secondary effects.

\section{Potential solutions, probable benefits}

In a previous pilot study, we evaluated the short-term effectiveness of a plant-based protein-redistributed diet on levodopa-treated PD patients. ${ }^{161}$ The intervention diet was strictly normoproteic, and nitrogen intake came exclusively from plant sources. Patients were free to assume ad libitum amounts of plant food with the only restriction being their distribution in the daytime. The diet was supplemented with vitamin B12 and provided a redistribution of the total daily protein amount, reserving $2 / 3-3 / 4$ of the total daily protein for the evening meal. After a 1-month period, the intervention group showed a significant improvement in neurological performance and stage compared with a control group of $\mathrm{PD}$ patients receiving their usual omnivorous protein-redistributed diet. The basic menu plan is shown in Table 3, which proposes both the omnivorous and the vegan alternatives. ${ }^{161}$ Choices about the composition of breakfast, lunch, and the two snacks are the same in the two patterns. At dinner, patients following the omnivorous diet could eat animal food, while in the vegan pattern the protein-rich

Table 3 Basic menu plan to limit and redistribute total protein intake: omnivorous and vegan options

\begin{tabular}{|c|c|c|c|}
\hline \multicolumn{2}{|l|}{ Omnivorous } & \multicolumn{2}{|l|}{ Vegan } \\
\hline Allowed foods & Avoided foods & Proposed foods & Exchange list \\
\hline \multicolumn{4}{|l|}{ Breakfast } \\
\hline Tea, coffee & Milk $^{a}$ & Tea & Coffee \\
\hline Bread & & Bread & \\
\hline \multicolumn{4}{|l|}{ Lunch } \\
\hline $\begin{array}{l}\text { Pasta, rice, or other cereals with } \\
\text { vegetables and oil }\end{array}$ & Parmesan cheese & $\begin{array}{l}\text { Pasta (with tomato, vegetables, } \\
\text { olive oil, and spices) }\end{array}$ & $\begin{array}{l}\text { Rice, other cereals, same amount } \\
\text { (with vegetables, olive oil, and spices) }\end{array}$ \\
\hline Bread or potatoes & & Bread & Potatoes (baked, boiled), 3-4/week \\
\hline Vegetables, raw or cooked (ad libitum) & $\begin{array}{l}\text { Meat, }{ }^{\mathrm{a}} \text { fish, }{ }^{\mathrm{a}} \text { cheese, }{ }^{\mathrm{a}} \text { eggs, }{ }^{\mathrm{a}} \\
\text { pulses and their products }\end{array}$ & Vegetables, raw or cooked (ad libitum) & \\
\hline Fruit, raw or cooked (ad libitum) & & Fruit, raw or cooked (ad libitum) & \\
\hline \multicolumn{4}{|l|}{ Dinner } \\
\hline Pasta, rice, or other cereals & & Pasta (in vegetable soup with beans) & $\begin{array}{l}\text { Rice, other cereals, same amount } \\
\text { (in vegetable soup with beans) }\end{array}$ \\
\hline $\begin{array}{l}\text { Meat, }{ }^{a} \text { fish, }{ }^{a} \text { cheese, }{ }^{a} \text { eggs, }{ }^{a} \text { pulses } \\
\text { and their products }\end{array}$ & & Pulses (beans, chickpeas, lentils, peas) & $\begin{array}{l}\text { Pulses soup with vegetables, whole } \\
\text { grains, or bread }\end{array}$ \\
\hline Bread or potatoes & & Bread & Potatoes (baked, boiled), 3-4/week \\
\hline Vegetables, raw or cooked (ad libitum) & & Vegetables, raw or cooked (ad libitum) & \\
\hline Fruit, raw or cooked (ad libitum) & & Fruit, raw or cooked (ad libitum) & Nuts \\
\hline \multicolumn{4}{|c|}{2 snacks/day, in the morning and in the afternoon, with raw fruit (ad libitum) } \\
\hline \multicolumn{4}{|c|}{ Total olive oil: 30 mL/d (2 Tbs) } \\
\hline \multicolumn{4}{|c|}{$2,000 \mathrm{~mL} / \mathrm{d}$ of calcium-rich mineral water } \\
\hline \multicolumn{4}{|c|}{ Vitamin BI2 and vitamin D supplements mandatory } \\
\hline DHA algal supplement suggested & & & \\
\hline
\end{tabular}

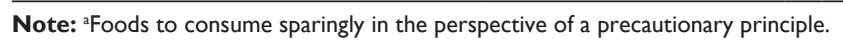

Abbreviations: DHA, docosahexaenoic acid; Tbs, tablespoons. 
Table 4 I,500 kcal basic menu plan to limit and redistribute total protein intake: average nutritional composition for omnivorous $(\mathrm{OMN})$ and vegan (VEG) options

\begin{tabular}{|c|c|c|c|c|c|c|}
\hline & \multicolumn{3}{|l|}{ Omnivorous } & \multicolumn{3}{|l|}{ Vegan } \\
\hline & \multicolumn{6}{|l|}{ Amount (g/d) } \\
\hline & Carbohydrate & Protein & Lipid & Carbohydrate & Protein & Lipid \\
\hline Breakfast & 18.60 & 4.26 & 3.00 & 18.60 & 4.26 & 3.00 \\
\hline Snack & 21.65 & 0.47 & 0.16 & 21.65 & 0.47 & 0.16 \\
\hline Lunch & 74.35 & 11.03 & 15.84 & 74.35 & 11.03 & 15.84 \\
\hline Snack & 20.12 & 2.03 & 1.58 & 20.12 & 2.03 & 1.58 \\
\hline Dinner & 68.52 & 49.17 & 31.32 & 98.76 & 31.59 & 26.39 \\
\hline \multirow[t]{3}{*}{ Total } & 203.24 & 66.97 & 51.90 & 233.48 & 49.39 & 46.97 \\
\hline & \multicolumn{6}{|l|}{ Calories (kcal/d) } \\
\hline & Carbohydrate & Protein & Lipid & Carbohydrate & Protein & Lipid \\
\hline Breakfast & 74.40 & 17.04 & 27.00 & 74.40 & 17.04 & 27.00 \\
\hline Snack & 86.58 & 1.90 & 1.42 & 86.58 & 1.90 & $\mathrm{I} .42$ \\
\hline Lunch & 297.42 & 44.13 & 142.60 & 297.42 & 44.13 & 142.60 \\
\hline Snack & 80.47 & 8.13 & 14.18 & 80.47 & 8.13 & 14.18 \\
\hline Dinner & 274.09 & 196.69 & 281.87 & 395.04 & 126.36 & 237.54 \\
\hline Total & 812.96 & 267.88 & 467.07 & 933.92 & 197.56 & 422.74 \\
\hline Percentage of total calories & 53 & 17 & 30 & 60 & 13 & 27 \\
\hline Total calories/d & $\mathrm{I}, 504$ & & & 1,503 & & \\
\hline \multirow[t]{2}{*}{ Water $(\mathrm{mL} / \mathrm{d})$} & $2,752.05$ & & & $2,856.0$ & & \\
\hline & \multicolumn{6}{|c|}{ Micronutrient composition (mean)/d } \\
\hline Calcium (mg) & 916.0 & & & 896.0 & & \\
\hline Phosphorus (mg) & 890.0 & & & 830.0 & & \\
\hline Iron (mg) & 12.2 & & & 18.0 & & \\
\hline Sodium (mg) & 530.0 & & & 112.0 & & \\
\hline Potassium (mg) & $2,212.0$ & & & $3,116.0$ & & \\
\hline Fiber $(\mathrm{g})$ & 27.4 & & & 41.5 & & \\
\hline Cholesterol (mg) & 129.0 & & & 0.0 & & \\
\hline Retinol Eq ( $\mu \mathrm{g})$ & 721.0 & & & $\mathrm{I}, 258.0$ & & \\
\hline Vitamin C (mg) & 134.0 & & & 237.0 & & \\
\hline Vitamin BI (mg) & 0.8 & & & 0.9 & & \\
\hline Vitamin B2 (mg) & $\mathrm{I} .4$ & & & I.I & & \\
\hline
\end{tabular}

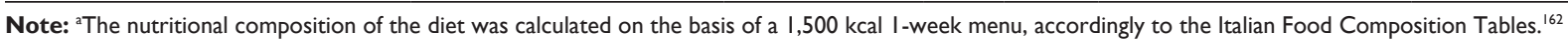

food was only of plant-origin. The daily nutritional composition of the two patterns, calculated on a weekly basis, is shown in Table 4. ${ }^{161,162}$ In PD patients not requiring protein redistribution, the same daily total foods can be consumed in other different meals.

\section{Conclusion}

Diet can contribute to the clinical status of PD patients and to the disease progression, both by altering the nutrition status and by interfering with the pharmacologic treatment. It is also probable that diet can influence the function and integrity of some neurological pathways. Energy, fluid, nutrient intake and food-drug interactions can all be causative factors, and require an optimal nutritional intervention, which should even be considered as secondary prevention. A well-balanced plant-based diet as well as (in responder levodopa-treated patients) the limitation to RDA of total daily protein intake and its redistribution can favorably influence the disease outcomes. Since the subjective acceptability of a diet can affect long-term dietary compliance and effects, it should be highlighted that, unlike other medical conditions, responder PD patients can almost immediately experience relief from motor symptoms and side effects, which in turn make even drastic dietary changes acceptable. ${ }^{34}$ No matter how drastic, however, the reported acceptability of vegetarian and vegan diets in clinical studies were found to be comparable to the other therapeutic nutritional regimens. ${ }^{163,164}$

Neuroprotection represents an emerging challenge in the field of PD research, but the neuroprotective benefits we hypothesized in this paper are presently only at a speculative status, and new intervention studies are warranted to establish whether the application of a plant-based diet can 
positively influence some of the different aspects modulating the development and progression of the disease. Diet can be involved in nutrition-gene interactions, ie, influencing epigenetic regulation of gene expression. ${ }^{61}$ Telomere shortening and dysfunction have been linked to age-related diseases like Parkinson's and Alzheimer's disease, ${ }^{165}$ and nutrients can potentially influence telomere length. This field of research is still at a very early stage, but the results of a 5-year-follow-up small pilot study involving a group of subjects who underwent a comprehensive lifestyle intervention, including a plantbased diet, are promising. The intervention was associated with a smaller decrease in telomerase activity and a relative increase in telomere length. ${ }^{166}$

Apart from any speculation, a plant-based menu seems to be a convenient way to manipulate protein intake and increase fiber intake. The reduction of dietary protein to normal requirements, the prevention of excessive LNAA intake, and the redistribution of daily protein so that most protein is consumed at the evening meal, together with higher fiber intakes, can all optimize the effectiveness of levodopa treatment. Such intervention can be effective in the short-term and as well as in the long-term, allowing for the reduction of drug doses and the limitation of their iatrogenic effects (orthostatic hypotension, gastrointestinal symptoms, hyperhomocysteinemia). Improving motor performance and levodopa response can moreover delay the progression of the disease.

So, neurologists following PD patients should become experienced not only in pharmacological options, but also in the nutritional aspects of disease management. They may require the counseling of a dietitian who is expert in all implications of nutrition in PD. Patients should be periodically checked to evaluate the cost-benefit ratio of a comprehensive approach to the disease, which should no longer rely only on drugs. If strong evidence is lacking, and people need advice, the principle of precaution is always valid.

\section{Acknowledgments}

The authors thank the anonymous reviewers who made many useful suggestions to improve the manuscript. The authors wish to thank Dr Paul Griffith for his valuable suggestions and for the revision of the manuscript.

\section{Disclosure}

The authors report no conflict of interest in this work.

\section{References}

1. Mena I, Cotzias GC. Protein intake and treatment of Parkinson's disease with levodopa. N Engl J Med. 1975;292(4):181-184.
2. Gasser T, Müller-Myhsok B, Wszolek ZK, et al. A susceptibility locus for Parkinson's disease maps to chromosome 2p13. Nat Genet. 1998;18(3):262-265.

3. Jarman P, Wood N. Parkinson's disease genetics comes of age. BMJ. 1999;318(7199):1641-1642.

4. Lazzarini AM, Myers RH, Zimmerman TR Jr, et al. A clinical genetic study of Parkinson's disease: evidence for dominant transmission. Neurology. 1994;44(3 Pt 1):499-506.

5. Scott WK, Nance MA, Watts RL, et al. Complete genomic screen in Parkinson disease: evidence for multiple genes. JAMA. 2001;286(18):2239-2244.

6. Behari M, Srivastava AK, Das RR, Pandey RM. Risk factors of Parkinson's disease in Indian patients. J Neurol Sci. 2001;190(1-2):49-55.

7. Ben-Shlomo Y. How far are we in understanding the cause of Parkinson's disease? J Neurol Neurosurg Psychiatry. 1996;61(1):4-16.

8. Tanner CM, Goldman SM. Epidemiology of Parkinson's disease. Neurol Clin. 1996;14(2):317-335.

9. Zuber M, Alperovitch A. [Parkinson's disease and environmental factors]. Rev Epidemiol Sante Publique. 1991;39(4):373-387. French.

10. Tanner CM, Chen B, Wang WZ, et al. Environmental factors in the etiology of Parkinson's disease. Can J Neurol Sci. 1987; 14(Suppl 3):419-423.

11. Zhang ZX, Román GC. Worldwide occurrence of Parkinson's disease: an updated review. Neuroepidemiology. 1993;12(4):195-208.

12. McCarty MF. Does vegan diet reduce risk of Parkinson's disease? Med Hypotheses. 2001;57(3):318-323.

13. Beyer PL, Palarino MY, Michalek D, Busenbark K, Koller WC. Weight change and body composition in patients with Parkinson's disease. J Am Diet Assoc. 1995;95(9):979-983.

14. Cushing ML, Traviss KA, Calne SM. Parkinson's disease: implications for nutritional care. Can J Diet Pract Res. 2002;63(2):81-87.

15. Tuite PJ, Maxwell RE, Ikramuddin S, et al. Weight and body mass index in Parkinson's disease patients after deep brain stimulation surgery. Parkinsonism Relat Disord. 2005;11(4):247-252.

16. Uc EY, Struck LK, Rodnitzky RL, Zimmerman B, Dobson J, Evans WJ. Predictors of weight loss in Parkinson's disease. Mov Disord. 2006; 21(7):930-936.

17. van der Marck MA, Dicke HC, Uc EY, et al. Body mass index in Parkinson's disease: a meta-analysis. Parkinsonism Relat Disord. 2012;18(3):263-267.

18. Sheard JM, Ash S, Silburn PA, Kerr GK. Prevalence of malnutrition in Parkinson's disease: a systematic review. Nutr Rev. 2011;69(9): 520-532.

19. Barichella M, Villa MC, Massarotto A, et al. Mini Nutritional Assessment in patients with Parkinson's disease: correlation between worsening of the malnutrition and increasing number of disease years. Nutr Neurosci. 2008;11(3):128-134.

20. Sheard JM, Ash S, Mellick GD, Silburn PA, Kerr GK. Malnutrition in a sample of community-dwelling people with Parkinson's disease. PLoS One. 2013;8(1):e53290.

21. Sheard JM, Ash S, Mellick GD, Silburn PA, Kerr GK. Markers of disease severity are associated with malnutrition in Parkinson's disease. PLoS One. 2013;8(3):e57986.

22. Arabia G, Zappia M, Bosco D, et al. Body weight, levodopa pharmacokinetics and dyskinesia in Parkinson's disease. Neurol Sci. 2002; 23 Suppl 2:S53-S54.

23. Bachmann CG, Zapf A, Brunner E, Trenkwalder C. Dopaminergic treatment is associated with decreased body weight in patients with Parkinson's disease and dyskinesias. Eur J Neurol. 2009;16(8):895-901.

24. Sharma JC, Macnamara L, Hasoon M, Vassallo M, Ross I. Cascade of levodopa dose and weight-related dyskinesia in Parkinson's disease (LDWD-PD cascade). Parkinsonism Relat Disord. 2006;12(8):499-505.

25. Kumru H, Santamaria J, Valldeoriola F, Marti MJ, Tolosa E. Increase in body weight after pramipexole treatment in Parkinson's disease. Mov Disord. 2006;21(11):1972-1974.

26. Nirenberg MJ, Waters C. Compulsive eating and weight gain related to dopamine agonist use. Mov Disord. 2006;21(4):524-529. 
27. Raja M, Bentivoglio AR. Impulsive and compulsive behaviors during dopamine replacement treatment in Parkinson's Disease and other disorders. Curr Drug Saf. 2012;7(1):63-75.

28. Barichella M, Marczewska AM, Mariani C, Landi A, Vairo A, Pezzoli G. Body weight gain rate in patients with Parkinson's disease and deep brain stimulation. Mov Disord. 2003;18(11):1337-1340.

29. Gironell A, Pascual-Sedano B, Otermin P, Kulisevsky J. [Weight gain after functional surgery for Parkinsons disease]. Neurologia. 2002; 17(6):310-316. Spanish.

30. Perlemoine C, Macia F, Tison F, et al. Effects of subthalamic nucleus deep brain stimulation and levodopa on energy production rate and substrate oxidation in Parkinson's disease. Br J Nutr. 2005;93(2):191-198.

31. Macia F, Perlemoine C, Coman I, et al. Parkinson's disease patients with bilateral subthalamic deep brain stimulation gain weight. Mov Disord. 2004;19(2):206-212.

32. Kistner A, Lhommée E, Krack P. Mechanisms of body weight fluctuations in Parkinson's disease. Front Neurol. 2014;5:84.

33. Deleu D, Northway MG, Hanssens Y. Clinical pharmacokinetic and pharmacodynamic properties of drugs used in the treatment of Parkinson's disease. Clin Pharmacokinet. 2002;41:261-309.

34. Kempster PA, Wahlqvist ML. Dietary factors in the management of Parkinson's disease. Nutr Rev. 1994;52(2 Pt 1):51-58.

35. Schwartz SE, Levine RA, Singh A, Scheidecker JR, Track NS. Sustained pectin ingestion delays gastric emptying. Gastroenterology. 1982;83(4): 812-817.

36. Astarloa R, Mena MA, Sánchez V, de la Vega L, de Yébenes JG. Clinical and pharmacokinetic effects of a diet rich in insoluble fiber on Parkinson disease. Clin Neuropharmacol. 1992;15(5):375-380.

37. Khor SP, Hsu A. The pharmacokinetics and pharmacodynamics of levodopa in the treatment of Parkinson's disease. Curr Clin Pharmacol. 2007;2(3):234-243.

38. Nutt JG, Fellman JH. Pharmacokinetics of levodopa. Clin Neuropharmacol. 1984;7(1):35-49.

39. Pardridge WM. Kinetics of competitive inhibition of neutral amino acid transport across the blood-brain barrier. J Neurochem. 1977;28(1): $103-108$.

40. Leenders KL, Poewe WH, Palmer AJ, Brenton DP, Frackowiak RS. Inhibition of L-[18F]fluorodopa uptake into human brain by amino acids demonstrated by positron emission tomography. Ann Neurol. 1986;20(2):258-262.

41. Nutt JG, Woodward WR, Carter JH, Trotman TL. Influence of fluctuations of plasma large neutral amino acids with normal diets on the clinical response to levodopa. J Neurol Neurosurg Psychiatry. 1989;52(4):481-487.

42. Nutt JG, Carter JH, Lea ES, Woodward WR. Motor fluctuations during continuous levodopa infusions in patients with Parkinson's disease. Mov Disord. 1997;12(3):285-292.

43. Pincus JH, Barry KM. Dietary method for reducing fluctuations in Parkinson's disease. Yale J Biol Med. 1987;60(2):133-137.

44. Pincus JH, Barry K. Influence of dietary protein on motor fluctuations in Parkinson's disease. Arch Neurol. 1987;44(3):270-272.

45. Pincus JH, Barry KM. Plasma levels of amino acids correlate with motor fluctuations in parkinsonism. Arch Neurol. 1987;44(10):1006-1009.

46. Eriksson T, Granérus AK, Linde A, Carlsson A. 'On-off' phenomenon in Parkinson's disease: relationship between dopa and other large neutral amino acids in plasma. Neurology. 1988;38(8):1245-1248.

47. Tsui JK, Ross S, Poulin K, et al. The effect of dietary protein on the efficacy of L-dopa: a double-blind study. Neurology. 1989;39(4):549-552.

48. Wajsbort J. [The “off-on" phenomenon during treatment of parkinson's disease with levodopa (author's transl)]. J Neurol. 1977;215(1):59-66. German.

49. Marczewska A, De Notaris R, Sieri S, Barichella M, Fusconi E, Pezzoli G. Protein intake in Parkinsonian patients using the EPIC food frequency questionnaire. Mov Disord. 2006;21(8):1229-1231.

50. Berry EM, Growdon JH, Wurtman JJ, Caballero B, Wurtman RJ. A balanced carbohydrate: protein diet in the management of Parkinson's disease. Neurology. 1991;41(8):1295-1297.
51. Bracco F, Malesani R, Saladini M, Battistin L. Protein redistribution diet and antiparkinsonian response to levodopa. Eur Neurol. 1991;31(2): 68-71.

52. Carter JH, Nutt JG, Woodward WR, Hatcher LF, Trotman TL. Amount and distribution of dietary protein affects clinical response to levodopa in Parkinson's disease. Neurology. 1989;39(4):552-556.

53. Pincus JH, Barry K. Protein redistribution diet restores motor function in patients with dopa-resistant "off" periods. Neurology. 1988;38(3): 481-483.

54. Giménez-Roldán S, Mateo D. Predicting beneficial response to a proteinredistribution diet in fluctuating Parkinson's disease. Acta Neurol Belg. 1991;91(4):189-200.

55. Karstaedt PJ, Pincus JH. Protein redistribution diet remains effective in patients with fluctuating parkinsonism. Arch Neurol. 1992;49(2): 149-151.

56. Giménez-Roldán S, Mateo D, García Almansa A, García Peris P. [Proposal for a protein redistribution diet in the control of motor fluctuations in Parkinson's disease: acceptance and efficacy]. Neurologia. 1991;6(1):3-9. Spanish.

57. Cereda E, Barichella M, Pedrolli C, Pezzoli G. Low-protein and protein-redistribution diets for Parkinson's disease patients with motor fluctuations: a systematic review. Mov Disord. 2010;25(13): 2021-2034.

58. Olanow CW, Koller WC. An algorithm (decision tree) for the management of Parkinson's disease: treatment guidelines. American Academy of Neurology. Neurology. 1998;50(3 Supp1 3):S1-S57.

59. Riley D, Lang AE. Practical application of a low-protein diet for Parkinson's disease. Neurology. 1988;38(7):1026-1031.

60. Nielsen SS, Franklin GM, Longstreth WT, Swanson PD, Checkoway H. Nicotine from edible Solanacee and risk of Parkinson disease. Ann Neurol. 2013;74(3):472-477.

61. Seidl SE, Santiago JA, Bilyk H, Potashkin JA. The emerging role of nutrition in Parkinson's disease. Front Aging Neurosci. 2014;6:36.

62. Shaltiel-Karyo R, Frenkel-Pinter M, Rockenstein E, et al. A boodbrain barrier (BBB) disrupter is also a potent $\alpha$-synuclein $(\alpha$-syn) aggregation inhibitor: a novel dual mechanism of mannitol for the treatment of Parkinson disease (PD). J Biol Chem. 2013;288(24):17579-17588.

63. Barnham KJ, Masters CL, Bush AI. Neurodegenerative diseases and oxidative stress. Nat Rev Drug Discov. 2004;3(3):205-214.

64. Maguire-Zeiss KA, Short DW, Federoff HJ. Synuclein, dopamine and oxidative stress: co-cospirators in Parkinson's disease? Brain Res Mol Brain Res. 2005;134(1):18-23.

65. Scheider WL, Hershey LA, Vena JE, Holmlund T, Marshall JR, Freudenheim. Dietary antioxidants and other dietary factors in the etiology of Parkinson's disease. Mov Disord. 1997;12(2):190-196.

66. de Rijk MC, Breteler MM, den Breeijen JH, et al. Dietary antioxidants and Parkinson disease. The Rotterdam Study. Arch Neurol. 1997;54(6): 762-765.

67. Etminan M, Gill SS, Samii A. Intake of vitamin E, vitamin C, and carotenoids and the risk of Parkinson's disease: a meta-analysis. Lancet Neurol. 2005;4(6):362-365.

68. Miyake Y, Fukushima W, Tanaka K, et al. Dietary intake of antioxidant vitamins and risk of Parkinson's disease: a case-control study in Japan. Eur J Neurol. 2011;18(1):106-113.

69. Zhang SM, Hernán MA, Chen H, Spiegelman D, Willett WC, Ascherio A. Intakes of vitamins $\mathrm{E}$ and $\mathrm{C}$, carotenoids, vitamin supplements, and PD risk. Neurology. 2002;59(8):1161-1169.

70. Li Y, Liu L, Barger SW, Mrak RE, Griffin WS. Vitamin E suppression of microglial activation is neuroprotective. J Neurosci Res. 2001;66(2): $163-170$.

71. Grunewald RA. Ascorbic acid in the brain. Brain Res Brain Res Rev. 1993;18(1):123-133.

72. Fahn S. A pilot trial of high-dose alpha-tocopherol and ascorbate in early Parkinson's disease. Ann Neurol. 1992;32 Suppl:S128-S132.

73. Jiménez-Jiménez FJ, Molina JA, Fernández-Calle P, et al. Serum levels of beta-carotene and other carotenoids in Parkinson's disease. Neurosci Lett. 1993;157(1):103-106. 
74. Upchurch GR Jr, Welch GN, Fabian AJ, et al. Homocyst(e)ine decreases bioavailable nitric oxide by a mechanism involving glutathione peroxidase. J Biol Chem. 1997;272(27):17012-17017.

75. Chen H, Zhang SM, Schwarzschild MA, et al. Folate intake and risk of Parkinson's disease. Am J Epidemiol. 2004;160(4):368-375.

76. de Lau LM, Koudstaal PJ, Witteman JC, Hofman A, Breteler MM. Dietary folate, vitamin B12, and vitamin B6 and the risk of Parkinson disease. Neurology. 2006;67(2):315-318.

77. Murakami K, Miyake Y, Sasaki S, et al. Dietary intake of folate, vitamin B6, vitamin B12 and riboflavin and risk of Parkinson's disease: a casecontrol study in Japan. Br J Nutr. 2010;104(5):757-764.

78. Ding H, Dhima K, Lockhart KC, et al. Unrecognized vitamin D3 deficiency is common in Parkinson disease: Harvard Biomarker Study. Neurology. 2013;81(17):1531-1537.

79. Peterson AL. A review of vitamin D and Parkinson's disease. Maturitas. 2014;78(1):40-44.

80. Ngim CH, Devathasan G. Epidemiologic study on the association between body burden mercury level and idiopathic Parkinson's disease. Neuroepidemiology. 1989;8(3):128-141.

81. Johnson CC, Gorell JM, Rybicki BA, Sanders K, Peterson EL. Adult nutrient intake as a risk factor for Parkinson's disease. Int J Epidemiol. 1999;28(6):1102-1109.

82. Logroscino G, Marder K, Graziano J, et al. Dietary iron, animal fats, and risk of Parkinson's disease. Mov. Disord. 1998;13 Suppl 1:13-16.

83. Powers KM, Smith-WellerT, Franklin GM, Longstreth WT Jr, Swanson PD, Checkoway H. Parkinson's disease risks associated with dietary iron, manganese, and other nutrient intakes. Neurology. 2003;60(11): 1761-1766.

84. Schipper HM. Heme oxygenase-1: role in brain aging and neurodegeneration. Exp Gerontol. 2000;35(6-7):821-830.

85. Anderson C, Checkoway H, Franklin GM, Beresford S, Smith-Weller T, Swanson PD. Dietary factors in Parkinson's disease: the role of food groups and specific foods. Mov Disord. 1999;14(1):21-27.

86. Logroscino G, Marder K, Cote L, Tang MX, Shea S, Mayeux R. Dietary lipids and antioxidants in Parkinson's disease: a population-based, case-control study. Ann Neurol. 1996;39(1):89-94.

87. Chen H, Zhang SM, Hernan MA, Willett WC, Ascherio A. Dietary intake of fat and risk of Parkinson's disease. Am J Epidemiol. 2003;157(11):1007-1014.

88. Hellenbrand W, Boeing H, Robra BP, et al. Diet and Parkinson's disease. II: a possible role for the past intake of specific nutrients. Result from a self-administered food-frequency questionnaire in a case-control study. Neurology. 1996;47(3):644-650.

89. Peers R. Fatty diet, mitochondria and Parkinson's disease. $N Z$ Med J. 1997;110(1041):132.

90. de Lau LM, Bornebroek M, Witteman JC, Hofman A, Koudstaal PJ, Breteler MM. Dietary fatty acids and the risk of Parkinson disease: the Rotterdam study. Neurology. 2005;64(12):2040-2045.

91. Kamel F, Goldman SM, Umbach DM, et al. Dietary fat intake, pesticide use, and Parkinson's disease. Parkinsonism Relat Disord. 2014;20(1):82-87.

92. Morens DM, Grandinetti A, Waslien CI, Park CB, Ross GW, White LR. Case-control study of idiopathic Parkinson's disease and dietary vitamin E intake. Neurology. 1996;46(5):1270-1274.

93. Ghosh A, Saminathan H, Kanthasamy A, et al. The peptidyl-prolyl isomerase Pin1 up-regulation and proapoptotic function in dopaminergic neurons: relevance to the pathogenesis of Parkinson disease. $J$ Biol Chem. 2013;288(30):21955-21971.

94. Ryo A, Togo T, Nakai T, et al. Prolyl-isomerase Pin1 accumulates in lewy bodies of Parkinson disease and facilitates formation of alphasynuclein inclusions. J Biol Chem. 2006;281:4117-4125.

95. Chen H, O'Reilly E, McCullough ML, et al. Consumption of dairy products and risk of Parkinson's disease. Am J Epidemiol. 2007;165(9): 998-1006.

96. Kyrozis A, Ghika A, Stathopoulos P, Vassilopoulos D, Trichopoulos D, Trichopoulou A. Dietary and lifestyle variables in relation to incidence of Parkinson's disease in Greece. Eur J Epidemiol. 2013;28(1):67-77.
97. Park M, Ross GW, Petrovitch H, et al. Consumption of milk and calcium in midlife and the future risk of Parkinson disease. Neurology. 2005;64(6):1047-1051.

98. Chen H, Zhang SM, Hernán MA, Willett WC, Ascherio A. Diet and Parkinson's disease: a potential role of dairy products in men. Ann Neurol. 2002;52(6):793-801.

99. Behrooz RD, Sahebi S, Majnoni F, Ahmadpour M, Hoseini SH. Mercury contamination in commercial fresh and salt water fish of the Zabol Chahnimeh reservoirs and the Gulf of Oman (Iran). Food Addit Contam Part B Surveill. 2013;6(3):175-180.

100. Bravo AG, Cosio C, Amouroux D, et al. Extremely elevated methyl mercury levels in water, sediment and organisms in a Romanian reservoir affected by release of mercury from a chlor-alkali plant. Water Res. 2014;49:391-405.

101. Chételat J, Amyot M, Arp P, et al. Mercury in freshwater ecosystems of the Canadian Arctic: Recent advances on its cycling and fate. Sci Total Environ. Epub June 30, 2014.

102. Johnsson C, Schütz A, Sällsten G. Impact of consumption of freshwater fish on mercury levels in hair, blood, urine, and alveolar air. J Toxicol Environ Health A. 2005;68(2):129-140.

103. Sources of mercury pollution and the methylmercury contamination of fish in Minnesota [webpage on the Internet]. Minnesota: Minnesota Pollution Control Agency (MPCA); 2013. Available from: http://www. pca.state.mn.us/index.php/view-document.html?gid=288. Accessed October 25, 2014

104. National Study of Chemical Residues in Lake Fish Tissue [webpage on the Internet]. Washington (DC): United States Environmental Protection Agency; 2009. Available from: http://water.epa.gov/scitech/swguidance/ fishstudies/results.cfm\#results1. Accessed October 25, 2014.

105. Ascherio A, Zhang SM, Hernán MA, et al. Prospective study of caffeine consumption and risk of Parkinson's disease in men and women. Ann Neurol. 2001;50(1):56-63.

106. Costa J, Lunet N, Santos C, Santos J, Vaz-Corneiro A. Caffeine exposure and the risk of Parkinson's disease: a systematic review and meta-analyis of observational studies. J Alzheimers Dis. 2010; 20 Suppl 1:S221-S238.

107. Hu G, Bidel S, Jousilahti P, Antikainen R, Tuomilehto J. Coffee and tea consumption and the risk of Parkinson's disease. Mov Disord. 2007;22(15):2242-2248.

108. Ross GW, Abbott RD, Petrovitch H, et al. Association of coffee and caffeine intake with the risk of Parkinson disease. JAMA. 2000;283(20):2674-2679.

109. Sääksjärvi K, Knekt P, Rissanen H, Laaksonen MA, Reunanen A, Männistö S. Prospective study of coffee consumption and risk of Parkinson's disease. Eur J Clin Nutr. 2008;62(7):908-915.

110. Ascherio A, Chen H, Schwarzschild MA, Zhang SM, Colditz GA, Speizer FE. Caffeine, postmenopausal estrogen, and risk of Parkinson's disease. Neurology. 2003;60(5):790-795.

111. Ascherio A, Weisskopf MG, O'Reilly EJ, et al. Coffee consumption, gender, and Parkinson's disease mortality in the cancer prevention study II cohort: the modifying effects of estrogen. Am J Epidemiol. 2004;160(10):977-984.

112. Liu R, Guo X, Park Y, et al. Caffeine intake, smoking, and risk of Parkinson disease in men and women. Am J Epidemiol. 2012;175(11): 1200-1207.

113. Li FJ, Ji HF, Shen L. A meta-analysis of tea drinking and risk of Parkinson's disease. ScientificWorldJournal. 2012;2012:923464.

114. Pan T, Jankovic J, Le W. Potential therapeutic properties of green tea polyphenols in Parkinson's disease. Drugs Aging. 2003;20(10): 711-721.

115. Mandel SA, Amit T, Weinreb O, Youdim MB. Understanding the broad-spectrum neuroprotective action profile of green tea polyphenols in aging and neurodegenerative diseases. JAlzheimers Dis. 2011;25(2): 187-208.

116. Mandel SA, Weinreb O, Amit T, Youdim MB. Molecular mechanisms of the neuroprotective/neurorescue action of multi-target green tea polyphenols. Front Biosci (Schol Ed). 2012;4:581-598. 
117. Muangpaisan W, Mathews A, Hori H, Seidel D. A systematic review of the worldwide prevalence and incidence of Parkinson's disease. J Med Assoc Thai. 2011;94(6):749-755.

118. Scarmeas N, Stern Y, Tang MX, Mayeux R, Luchsinger JA. Mediterranean diet and risk for Alzheimer's disease. Ann Neurol. 2006;59(6):912-921.

119. Alcalay RN, GuY, Mejia-Santana H, Cote L, Marder KS, Scarmeas N. The association between Mediterranean diet adherence and Parkinson's disease. Mov Disord. 2012;27(6):771-774.

120. Gao X, Chen H, Fung TT, et al. Prospective study of dietary pattern and risk of Parkinson disease. Am J Clin Nutr. 2007;86(5): 1486-1494

121. Okubo H, Miyake Y, Sasaki S, et al. Dietary patterns and risk of Parkinson's disease: a case-control study in Japan. Eur J Neurol. 2012;19(5):681-688

122. Sofi F, Cesari F, Abbate R, Gensini GF, Casini A. Adherence to Mediterranean diet and health status: meta-analysis. BMJ. 2008;337:a1344.

123. Lopez-Garcia E, Schulze MB, Fung TT. Major dietary patterns are related to plasma concentrations of markers of inflammation and endothelial dysfunction. Am J Clin Nutr. 2004;80(4): 1029-1035.

124. Fung TT, McCullough ML, Newby PK, et al. Diet-quality scores and plasma concentrations of markers of inflammation and endothelial dysfunction. Am J Clin Nutr. 2005;82(1):163-173.

125. McGeer PL, McGeer EG. Inflammation and neurodegeneration in Parkinson's disease. Parkinsonism Relat Disord. 2004;10 Suppl 1: S3-S7.

126. Collier DS, Berg MJ, Fincham RW. Parkinsonism treatment: Part III Update. Ann Pharmacother. 1992;26(2):227-233.

127. Evatt ML. Nutritional therapies in Parkinson's disease. Curr Treat Options Neurol. 2007;9(3):198-204.

128. Håglin L, Selander B. [Diet in Parkinson disease]. Tidsskr Nor Laegeforen. 2000;120(5):576-578. Norwegian.

129. Barichella M, Cereda E, Pezzoli G. Major nutritional issues in the management of Parkinson's disease. Mov Disord. 2009;24(13) 1881-1892.

130. Institute of Medicine. Food and Nutrition Board, National Academies. Dietary Reference Intakes (DRIs). Washington (DC): National Academies Press; 2011. Available from: http://www.iom.edu/ Activities/Nutrition/SummaryDRIs/ /media/Files/Activity $\% 20$ Files/Nutrition/DRIs/5_Summary\%20Table\%20Tables\%201-4.pdf. Accessed August 22, 2014

131. Andrès E, Loukili NH, Noel E, et al. Vitamin B12 (cobalamin) deficiency in elderly patients. CMAJ. 2004;171(3):251-259.

132. Kumar N. Neurologic aspects of cobalamin (B12) deficiency. Handb Clin Neurol. 2014;120:915-926.

133. Lachner C, Steinle NI, Regenold WT. The neuropsychiatry of vitamin B12 deficiency in elderly patients. J Neuropsychiatry Clin Neurosci. 2012;24(1):5-15

134. Allen LH. How common is vitamin B-12 deficiency? Am J Clin Nutr. 2009;89(2):693S-696S.

135. Mahajan R, Gupta K. Revisiting metformin: annual vitamin B12 supplementation may become mandatory with long-term metformin use. J Young Pharm. 2010;2(4):428-429.

136. Wilhelm SM, Rjater RG, Kale-Pradhan PB. Perils and pitfalls of longterm effects of proton pump inhibitors. Expert Rev Clin Pharmacol. 2013;6(4):443-451.

137. USDA. Dietary Guidelines for Americans 2010. US Department of Agricolture and Department of Health and Human Services. Available from: http://www.cnpp.usda.gov/sites/default/files/dietary_guidelines_for_americans/PolicyDoc.pdf. Accessed November 23, 2014.

138. Messina V, Melina V, Mangels AR. A new food guide for North American vegetarians. J Am Diet Assoc. 2003;103(6):771-775.

139. Institute of Medicine (US) Committee to Review Dietary Reference Intakes for Vitamin D and Calcium; Ross AC, Taylor CL, Yaktine AL, et al, editors. Washington (DC): National Academies Press (US); 2011 .
140. Appleby P, Roddam A, Allen N, Key T. Comparative fracture risk in vegetarians and nonvegetarians in EPIC-Oxford. Eur J Clin Nutr. 2007;61(12):1400-1406.

141. Chiu JF, Lan SJ, Yang CY, et al. Long-term vegetarian diet and bone mineral density in postmenopausal Taiwanese women. Calcif Tissue Int. 1997;60(3):245-249.

142. Reed JA, Anderson JJ, Tylavsky FA, Gallagher PN Jr. Comparative changes in radial-bone density of elderly female lacto-ovovegetarians and omnivores. Am J Clin Nutr. 1994;59(5 Suppl):1197S-1202S.

143. Craig WJ, Mangels AR; American Dietetic Association. Position of the American Dietetic Association: vegetarian diets. J Am Diet Assoc. 2009;109(7):1266-1282.

144. Heaney RP, Dowell MS, Rafferty K, Bierman J. Bioavailability of the calcium in fortified soy imitation milk, with some observations on method. Am J Clin Nutr. 2000;71(5):1166-1169.

145. Heaney RP. Absorbability and utility of calcium in mineral waters. Am J Clin Nutr. 2006;84(2):371-374.

146. Van der Velde RY, Brouwers RB, Geusens PB, Lems WF, van den Bergh JP. Calcium and vitamin D supplementation: state of the art for daily practice. Food Nutr Res. 2014;58. Available from: http://dx.doi. org/10.3402/fnr.v58.21796. Accessed August 19, 2014.

147. Brouwer-Brolsma EM, Bischoff-Ferrari HA, Bouillon R, etal. Vitamin D: do we get enough? A discussion between vitamin D experts in order to make a step towards the harmonisation of dietary reference intakes for vitamin D across Europe. Osteoporos Int. 2013;24(5): $1567-1577$

148. Aloia JF. Clinical Review: The 2011 report on dietary reference intake for vitamin D: where do we go from here? J Clin Endocrinol Metab. 2011;96(10):2987-2996.

149. Salonen JT, Seppänen K, Nyyssönen K, et al. Intake of mercury from fish, lipid peroxidation, and the risk of myocardial infarction and coronary, cardiovascular, and any death in eastern Finnish men. Circulation. 1995;91(3):645-655.

150. EFSA. Scientific Opinion on Dietary Reference Values for fats, including saturated fatty acids, polyunsaturated fatty acids, monounsaturated fatty acids, trans fatty acids, and cholesterol. EFSA Journal. 2010;8(3):1461[107 pp]. Available from: http://www.efsa.europa.eu/ it/efsajournal/pub/1461.htm Accessed August 22, 2014.

151. Ryan L, Symington AM. Algal-oil supplements are a viable alternative to fish-oil supplements in terms of docosahexaenoic acid (22:6n-3 DHA). J Funct Foods. 2014. DOI: 10.1016/j.jff.2014.06.023.

152. USDA National Nutrient Database for Standard Reference [homepage on the Internet]. USDA; 2011. Available from: http://ndb.nal.usda.gov. Accessed August 16, 2014

153. Messina V, Mangels R, Messina M. The Dietitian's Guide to Vegetarian Diets: Issues and Applications. 3rd ed. Sudbury, MA: Jones and Bartlett Publishers; 2011.

154. Barichella M, Marczewska A, De Notaris R, et al. Special lowprotein foods ameliorate postprandial off in patients with advanced Parkinson's disease. Mov Disord. 2006;21(10):1682-1687.

155. Vilming ST. [Diet therapy in Parkinson disease] Tidsskr Nor Laegeforen. 1995;115(10):1244-1247. Norwegian.

156. Pare S, Barr SI, Ross SE. Effect of daytime protein restriction on nutrient intakes of free-living Parkinson's disease patients. Am J Clin Nutr. 1992;55(3):701-707.

157. Crowe FL, Appleby PN, Allen NE, Key TJ. Diet and risk of diverticular disease in Oxford cohort of European Prospective Investigation into Cancer and Nutrition (EPIC): prospective study of British vegetarians and non-vegetarians. BMJ. 2011;343:d4131.

158. Key TJ, Davey GK, Appleby PN. Health benefits of a vegetarian diet Proc Nutr Soc. 1999;58(2):271-275.

159. Senard JM, Brefel-Courbon C, Rascol O, Montastruc JL. Orthostatic hypotension in patients with Parkinson's disease: pathophysiology and management. Drugs Aging. 2001;18(7):495-505.

160. Rogers JD, Sanchez-Saffon A, Frol AB, Diaz-Arrastia R. Elevated plasma homocysteine levels in patients treated with levodopa: association with vascular disease. Arch. Neurol. 2003;60(1):59-64. 
161. Baroni L, Bonetto C, Tessan F, et al. Pilot dietary study with normoproteic protein-redistributed plant-food diet and motor performance in patients with Parkinson's disease. Nutr Neurosci. 2011;14(1): $1-9$.

162. Italian Research Institute for Food and Nutrition (INRAN). Tables of Food Composition. Update 2000, Carnovale and Marlettaeds, Milan (Italy): EDRA srlpublisher; (C) INRAN 2000.

163. Barnard ND, Gloede L, Cohen J, et al. A low-fat vegan diet elicits greater macronutrient changes, but is comparable in adherence and acceptability, compared with a more conventional diabetes diet among individuals with type 2 diabetes. J Am Diet Assoc. 2009;109(2): 263-272.
164. Barnard ND, Katcher HI, Jenkins DJ, Cohen J, Turner-McGrievy G. Vegetarian and vegan diets in type 2 diabetes management. Nutr Rev. 2009;67(5):255-263.

165. Paul L. Diet, nutrition and telomere length. J Nutr Biochem. 2011; 22(10):895-901.

166. Ornish D, Lin J, Chan JM, et al. Effect of comprehensive lifestyle changes on telomerase activity and telomere length in men with biopsyproven low-risk prostate cancer: 5-year follow-up of a descriptive pilot study. Lancet Oncol. 2013;14(11):1112-1120.

\section{Publish your work in this journal}

Journal of Parkinsonism and Restless Legs Syndrome is an online, open access, peer-reviewed journal. The journal publishes review articles, historical reviews, original research articles, case reports, letters to the editor, clinical teaching cases, neuroradiology highlights, neuropathology highlights, neuropsychiatry highlights, autobiographies, conference

\section{Dovepress}

proceedings, abstracts and book reviews. The manuscript management system is completely online and includes a very quick and fair peerreview system, which is all easy to use. Visit http://www.dovepress.com testimonials.php to read real quotes from published authors. 